\title{
PENGEMBANGAN MODEL INTEGRASI DELPHI-AHP- MARKOV DALAM PERENCANAAN KEBUTUHAN SUMBER DAYA MANUSIA
}

\author{
Ronald Sukwadi \\ Program Studi Teknik Industri \\ Universitas Katolik Indonesia Atma Jaya \\ Jl. Jenderal Sudirman 51 Jakarta \\ ronald.sukwadi@atmajaya.ac.id
}

\begin{abstract}
ABSTRAK
Sumber daya manusia (SDM) memiliki peran yang penting dalam mendukung realisasi rencana strategis maupun operasional suatu perusahaan. Oleh karena itu, kuantitas dan kualitas SDM yang akan direkrut suatu perusahaan membutuhkan suatu perencanaan kebutuhan SDM yang baik. Dalam penelitian ini, akan diberikan usulan atau pedoman jumlah dan komposisi, spesifikasi pegawai yang dibutuhkan, serta kebijakan pihak manajemen yang mendukung pemenuhan kebutuhan sumber daya manusia perusahaan. Metode Delphi, Analytical Hierarchy Process (AHP), dan rantai Markov digunakan dalam pengembangan model integrasi perencanaan SDM. Studi empiris di PT. BM digunakan dalam penerapan model integrasi tersebut.
\end{abstract}

Kata Kunci: perencanaan SDM, rantai Markov, Delphi, AHP

\section{PENDAHULUAN}

\section{A. Latar Belakang}

Sumber daya manusia (SDM) berperan sangat penting dalam meningkatkan daya saing perusahaan terhadap perusahaan lainnya. SDM yang dimiliki suatu perusahaan memiliki peran yang penting juga dalam mendukung realisasi rencana strategis dan operasional suatu perusahaan (Siswanto, 1989; Dessler, 1997; Noe et al., 1999; Belcourt and McBey, 2004). Salah satu hal yang perlu diperhatikan berkaitan dengan SDM adalah bagaimana suatu perusahaan dapat merencanakan kebutuhan akan SDM yang dibutuhkan untuk jangka waktu tertentu dengan baik (Burack, 1986; Rothwell, 1986) Ketidaksesuaian kuantitas dan kualitas sumber daya manusia yang direkrut suatu perusahaan dengan kebutuhan perusahaan tersebut akan memberikan efek negatif baik jangka pendek maupun jangka panjang bagi perusahaan itu sendiri (Rothwell, 1986; Meehan and Ahmed, 1990).

Pada penelitian ini akan dilakukan perencanaan jumlah dan komposisi sumber daya manusia pada PT. BM dengan menggunakan model integrasi Delphi-AHP-Markov. Pelaksanaan metode Delphi dilakukan dengan melakukan penyebaran kuesioner secara sekuensial kepada para ahli (Direktur Utama, Direktur Operasional, Direktur Marketing, Direktur Bagian Umum, Direktur Bagian Keuangan, dan Direktur Bagian Logistik) untuk mengetahui keadaan awal sumber daya manusia perusahaan, serta mengetahui kriteriakriteria yang berpengaruh bagi pihak manajemen perusahaan dalam membuat suatu kebijakan dalam hal pemenuhan kebutuhan sumber daya manusia perusahaan, sehingga diperoleh data yang bersifat kualitatif untuk kemudian dilakukan proses pembobotan (Andrean, 2008; Wijaya, 2006). 
Proses pembobotan dilakukan dengan pendekatan metode AHP (Analytical Hierarchy Process) untuk melakukan proses pengambilan keputusan yaitu memilih satu kriteria yang dianggap penting oleh pihak manajemen dalam membuat kebijakan yang mendukung pemenuhan kebutuhan sumber daya manusia perusahaan. Sedangkan untuk mengetahui jumlah dan komposisi pegawai yang dibutuhkan perusahaan di masa yang akan datang digunakan perhitungan kuantitatif rantai Markov. Berdasarkan hasil analisis kualitatif dan kuantitatif tersebut dapat dihasilkan pedoman yang lebih baik bagi perusahaan dalam melakukan perencanaan kebutuhan sumber daya manusianya.

\section{B. Tujuan Penelitian}

Adapun tujuan dari dilakukannya penelitian antara lain :

1. Menentukan kriteria-kriteria yang dianggap penting oleh pihak manajemen dalam membuat suatu kebijakan perusahaan yang dapat diterapkan pihak manajemen perusahaan untuk mendukung perencanaan tenaga kerja dengan menggunakan pendekatan Metode Delphi.

2. Memilih satu kriteria tersebut dari alternatif-alternatif kriteria yang ada. Pemilihan kriteria dilakukan dengan menggunakan pendekatan metode AHP (Analytical Hierarchy Process).

3. Memberikan usulan berupa hasil perencanaan jumlah dan komposisi kebutuhan pegawai di masa yang akan datang dengan menggunakan metode Markov.

\section{LANDASAN TEORI}

\section{A. Rencana Strategis Perusahaan and Perencanaan SDM}

Pada suatu perusahaan, masalah mengenai perekrutan, pemilihan, penempatan, dan pelatihan pegawai, dalam hal ini khususnya pada perusahaan berskala besar, proses ini membutuhkan waktu berbulan-bulan bahkan sampai bertahun-tahun. Keputusan suatu perusahaan untuk melakukan perekrutan personel / pegawai merupakan suatu hal yang bersifat strategis dan akan memberikan dampak jangka panjang bagi perusahaan tersebut (Burack, 1986; Jackson and Schuller, 1995; Belcourt and McBey, 2004). Oleh karena itu, manajemen perusahaan harus melakukan peramalan terhadap kebutuhan dan suplai sumber daya manusia sebagai bagian dari permasalahan dan perencanaan perusahaan. Kebutuhan jangka panjang perusahaan, kebijakan promosi jabatan, dan perekrutan harus disesuaikan sehingga kebutuhan dan ketersediaan terhadap sumber daya manusia dapat terpenuhi (Rothwell, 1986; Meehan and Ahmed, 1990; McClean, 1991).

Menentukan kebutuhan jangka panjang terhadap sumber daya manusia berkaitan erat dengan rencana strategis perusahaan. Rencana strategis perusahaan harus mengandung dasar informasi mengenai bagaimana rencana terhadap sumber daya manusia dapat dibuat (Rothwell, 1986). Hal lainnya yang harus diperhatikan oleh pihak manajemen adalah ketersediaan tenaga kerja yang ada ketika rencana strategis perusahaan dibuat, karena ketersediaan sumber daya manusia mempengaruhi apakah rencana strategis perusahaan tersebut dapat dilakukan (Belcourt and McBey, 2004). Bagan berikut memperlihatkan hubungan timbal balik hal-hal diatas : 


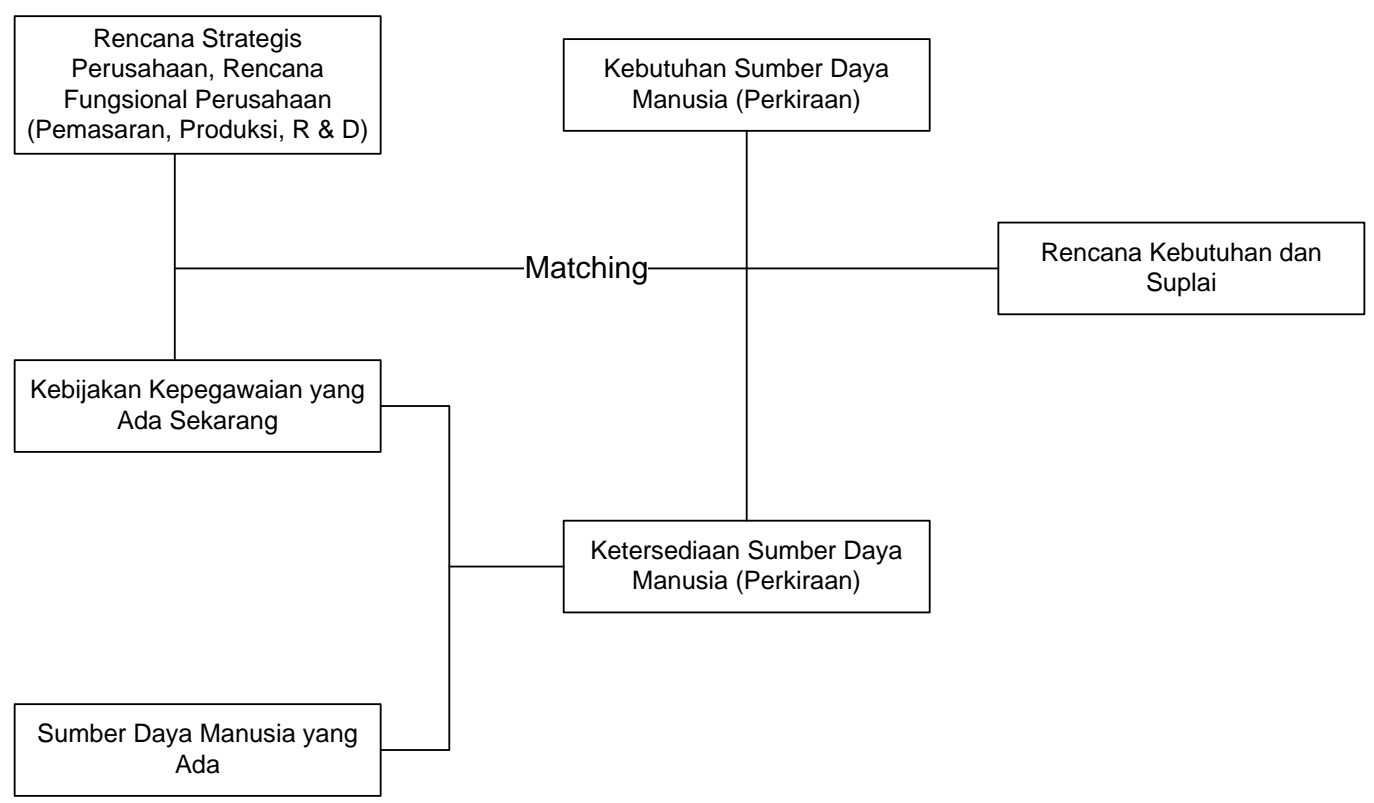

Gambar 1. Hubungan Rencana Strategis Perusahaan Dengan Perencanaan SDM

\section{B. Proses Delphi}

Metode Delphi digunakan dan dipopulerkan pada awal tahun 1960-an oleh RAND, sebuah lembaga penelitian di Santa Monica, California, Amerika Serikat. Metode Delphi merupakan suatu metode yang dilakukan dengan membentuk suatu kelompok atau komunikasi grup yang terdiri dari para ahli untuk membahas suatu permasalahan. Umumnya para ahli yang dilibatkan merupakan para ahli yang memiliki keahlian di bidang permasalahan yang sedang dibahas. Para ahli yang ada tidak saling mengetahui siapa saja yang terlibat di dalamnya sampai nantinya dipertemukan pada tahap akhir dari pelaksanaan metode Delphi ini (Gordon, 1994; Linston and Turrof, 2002).

Proses pelaksanaan metode Delphi yang umum dilakukan sekarang ini terdiri dari dua metode/versi (Linstone and Turoff, 2002) : "Paper and Pencil Version”, dimana pada metode ini suatu tim dibentuk untuk mendesain suatu kuesioner yang nantinya akan diajukan kepada para ahli (responden grup). Setelah semua jawaban dari kuesioner didapat, setiap responden diberikan kesempatan untuk kembali mengevaluasi jawaban mereka. Setelah itu, tim menyimpulkan hasil jawaban yang didapat tersebut. Berdasarkan kesimpulan tersebut, tim kembali merancang kuesioner tahap selanjutnya untuk kembali diajukan kepada kelompok responden. Metode Delphi seperti ini dikenal juga dengan nama "Conventional Delphi”.

Metode atau versi lainnya dari metode Delphi adalah "Delphi Conference”. Pada versi ini, metode Delphi dilaksanakan dengan menggunakan suatu sistem komputer yang telah diprogram, yang nantinya akan membantu kerja dari tim untuk menyimpulkan jawaban yang diperoleh dari tiap tahap kuesioner yang diajukan. Keunggulan dari versi ini adalah menghemat waktu pelaksanaan dan menghindari terjadinya kesalahan dari tim dalam menyimpulkan jawaban yang diperoleh dari kuesioner yang diajukan. 
Umumnya pelaksanaan dari metode Delphi ini dilakukan dalam 4 tahap atau fase sbb (Gordon, 1994):

1. Pada fase pertama kuesioner yang diajukan bertujuan untuk melakukan eksplorasi terhadap hal atau permasalahan yang sedang dibahas dengan mengumpulkan informasi secukup mungkin dari kelompok responden.

2. Pengajuan kuesioner fase kedua bertujuan untuk mengetahui pandangan atau pendapat para responden terhadap permasalahan yang sedang dibahas. Pada fase kedua ini hasil yang didapat diteliti apakah terdapat pertentangan pendapat yang signifikan antar kelompok responden mengenai permasalahan yang dibahas.

3. Jika ada pertentangan, maka hal tersebut dijadikan dasar untuk mengetahui alasan mendasar yang menyebabkan pertentangan tersebut melalui pengajuan kuesioner tahap ketiga.

4. Pada fase keempat, seluruh hasil dan jawaban yang telah diperoleh pada tahap sebelumnya dipresentasikan kembali oleh tim kepada para ahli atau kelompok responden untuk dilakukan penyimpulan akhir terhadap permasalahan yang sedang dibahas. Penyampaian hasil yang diperoleh dapat dilakukan dalam bentuk mean atau median data.

\section{Analytical Hierarchy Process (AHP)}

Metode Analytical Hierarchy Process (AHP) dikembangkan oleh Prof. Thomas Lorie Saaty dari Wharston Business School untuk mencari ranking atau urutan prioritas dari berbagai alternatif dalam pemecahan suatu permasalahan. Di sini diperlukan penentuan prioritas dan uji konsistensi terhadap pilihan-pilihan yang telah dilakukan. Dalam situasi yang kompleks, pengambilan keputusan tidak dipengaruhi oleh satu faktor saja melainkan multifaktor dan mencakup berbagai jenjang maupun kepentingan (Saaty, 1980).

Pada dasarnya $A H P$ adalah suatu teori umum tentang pengukuran yang digunakan untuk menemukan skala rasio baik dari perbandingan berpasangan yang diskrit maupun kontinu. Perbandingan-perbandingan ini dapat diambil dari ukuran aktual atau skala dasar yang mencerminkan kekuatan perasaan dan preferensi relatif. AHP memiliki perhatian khusus tentang penyimpangan dari konsistensi, pengukuran dan ketergantungan di dalam dan di luar kelompok elemen strukturalnya. Analytic Hierarchy Process (AHP) mempunyai landasan aksiomatik yang terdiri dari (Saaty, 1980):

1. Resiprocal Comparison, yang mengandung arti bahwa matriks perbandingan berpasangan yang terbentuk harus bersifat berkebalikan. Misalnya, jika A adalah k kali lebih penting daripada B maka B adalah 1/ k kali lebih penting dari A.

2. Homogenity, yang mengandung arti kesamaan dalam melakukan perbandingan. Misalnya, tidak dimungkinkan membandingkan jeruk dengan bola tenis dalam hal rasa, akan tetapi lebih relevan jika membandingkan dalam hal berat.

3. Dependence, yang berarti setiap jenjang (level) mempunyai kaitan (complete hierarchy) walaupun mungkin saja terjadi hubungan yang tidak sempurna (incomplete hierarchy).

4. Expectation, yang artinya menonjolkan penilaian yang bersifat ekspektasi dan preferensi dari pengambilan keputusan. Penilaian dapat merupakan data kuantitatif maupun yang bersifat kualitatif.

Tahapan-tahapan pengambilan keputusan dalam metode $A H P$ pada dasarnya meliputi:

A. Mendefinisikan masalah dan menentukan solusi yang diinginkan

B. Membuat struktur hirarki yang diawali dengan tujuan umum, dilanjutkan dengan 
kriteria-kriteria, sub kriteria dan alternatif-alternatif pilihan yang ingin di ranking

C. Membentuk matriks perbandingan berpasangan yang menggambarkan kontribusi relatif atau pengaruh setiap elemen terhadap masing-masing tujuan atau kriteria yang setingkat di atasnya. Perbandingan dilakukan berdasarkan pilihan atau "judgment" dari pembuat keputusan dengan menilai tingkat kepentingan suatu elemen dibandingkan elemen lainnya

D. Menormalkan data yaitu dengan membagi nilai dari setiap elemen di dalam matriks yang berpasangan dengan nilai total dari setiap kolom.

E. Menghitung nilai eigen vector dan menguji konsistensinya, jika tidak konsisten pengambil data (preferensi) perlu diulangi. Nilai eigen vector yang dimaksud adalah nilai eigen vector maksimum yang diperoleh dengan menggunakan software Matlab maupun manual

F. Mengulangi langkah 3, 4, dan 5 untuk seluruh tingkat hirarki

G. Menghitung eigen vector dari setiap matriks perbandingan berpasangan. Nilai eigen vector merupakan bobot setiap elemen. Langkah ini mensintesis pilihan dan penentuan prioritas elemen-elemen pada tingkat hirarki terendah sampai pencapaian tujuan

H. Menguji konsistensi hirarki. Jika tidak memenuhi dengan $\mathrm{CR}<0,100$ maka penilaian harus diulang kembali.

\section{Rantai Markov}

Prosedur ini dikembangkan oleh seorang sarjana matematika Rusia yang bernama Andrei A. Markov. Analisis Markov adalah suatu metode yang mempelajari sifat-sifat suatu variabel pada masa sekarang yang didasarkan pada sifat-sifatnya di masa lalu dalam usaha menaksir sifat-sifat variabel yang sama di masa mendatang (Taha, 1982; Stewman, 1978; Zanarkis and Martin, 1980).

Karena proses Markov merupakan proses stokastik, maka proses Markov dapat kita nyatakan sebagai suatu proses stokastik $\{\mathrm{X}(\mathrm{t})\}$ dengan himpunan indeks $\mathrm{T}$ dan ruang keadaan I (suatu proses sebagai himpunan harga variabel acak X(t) yang mungkin) disebut proses Markov bila untuk semua $\mathrm{n}, \mathrm{n}=0,1,2, \ldots \ldots$ dan untuk tiap $t_{0}$ $<t_{1}<t_{2}<\ldots \ldots \ldots . .<t_{n}, t_{0}=0$, dan harga $X_{n}$ sebagai harga khusus variabel acak $\mathrm{X}\left(t_{n}\right), \quad$ terdapat $\quad \mathrm{P}\left\{\mathrm{X}\left(t_{n}\right) \leq \frac{x_{n}}{X\left(t_{0}\right)}=x_{0}, \quad \mathrm{X}\left(t_{1}\right)=x_{1}, \ldots \ldots, \mathrm{X}\left(t_{n-1}\right)=x_{n-1}\right\}=$ $\mathrm{P}\left\{\mathrm{X}\left(t_{n}\right) \leq \frac{x_{n}}{X\left(t_{n-1}\right)=X_{n-1}}\right\}$

Ini dapat kita artikan sebagai berikut :

- Distribusi peluang bersyarat dari $\mathrm{X}\left(t_{n}\right)$ untuk harga-harga $\mathrm{X}\left(t_{0}\right), \mathrm{X}\left(t_{1}\right), \ldots . ., \mathrm{X}\left(t_{n-1}\right)$ yang sudah diketahui tergantung hanya pada harga $\mathrm{X}\left(t_{n-1}\right)$, yaitu harga terdekat, dan tidak tergantung pada harga-harga $\mathrm{X}\left(t_{0}\right), \mathrm{X}\left(t_{1}\right), \ldots . ., \mathrm{X}\left(t_{n-2}\right)$.

- Harga P $\left\{\mathrm{X}\left(t_{n}\right) \leq \frac{X_{n}}{X\left(t_{n-1}\right)}=x_{n-1}\right\}$ disebut “peluang peralihan satu langkah” dari keadaan $X_{n-1}$ pada langkah (n-1) kepada keadaan $X_{n}$ pada langkah n.

- Atau, diketahui keadaan sistem pada saat sekarang, keadaan masa datang tidak tergantung pada keadaan masa lalu. 
- Atau, cukup mengetahui sejarah proses stokastik pada waktu $t_{n-1}$ untuk dapat menurunkan sifat-sifat proses pada waktu $t_{n}$.

Dengan demikian, hukum peluang dari proses Markov seluruhnya teruraikan dengan mengetahui (1) syarat awal yang diberikan oleh $\mathrm{P}\left\{\mathrm{X}\left(t_{0}\right) \leq x_{0}\right\}$, dan (2) himpunan distribusi peluang bersyarat yang diberikan untuk semua $0 \leq t_{m}<t_{n}, \mathrm{~m}, \mathrm{n}=$ $0,1,2, \ldots \ldots$ oleh $\mathrm{P}\left\{\mathrm{X}\left(t_{n}\right) \leq \frac{X_{n}}{X\left(t_{n-1}\right)}=x_{m}\right\}$ yang menentukan "distribusi peluang peralihan” dari proses Markov.

Identifikasi himpunan distribusi peluang peralihan untuk semua $0 \leq t_{m}<t_{n}$ untuk suatu proses Markov sembarang adalah sesuatu yang sangat sukar. Meskipun demikian, banyak persoalan praktis dapat dirumuskan sebagai proses Markov dalam hal mana distribusi peluang peralihan adalah fungsi dari selisih $\left(t_{n}-t_{m}\right)$ dan bebas dari $t_{n}$. Dalam hal ini, proses Markov kita sebut mempunyai distribusi peluang peralihan yang "homogen” atau "stasioner".

Dengan demikian, formula untuk peluang peralihan stasioner satu langkah ialah:

$$
\mathrm{P}\left\{\mathrm{X}\left(t_{n}\right) \leq \frac{X_{n}}{X\left(t_{n-1}\right)}=x_{n-1}\right\}=\mathrm{P}\left\{\mathrm{X}\left(t_{1}\right) \leq \frac{X_{n}}{X\left(t_{0}\right)}=x_{n-1}\right\}
$$

untuk semua $\mathrm{n}, \mathrm{n}=1,2, \ldots \ldots \ldots$

\section{METODOLOGI PENELITIAN}

Penelitian yang dilakukan mengikuti alur metodologi penelitian sebagai berikut :

\section{Analisa Kondis Awal SDM Perusahaan}

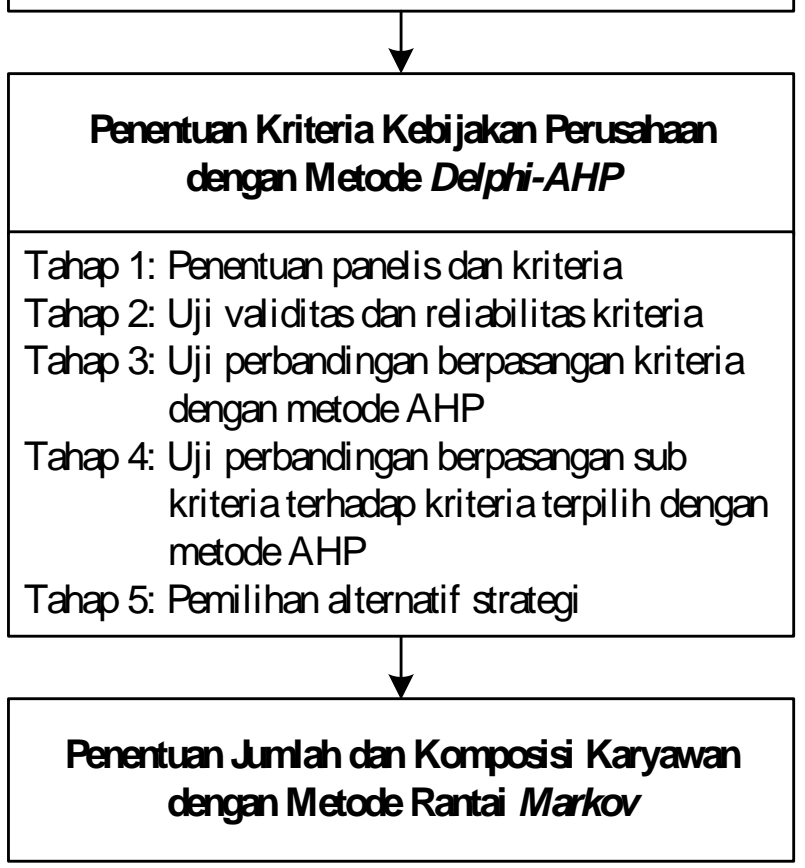

Gambar 2. Alur Metodologi Penelitian 


\section{HASIL DAN PEMBAHASAN}

\section{A. Analisa Kondisi Awal Sumber Daya Manusia Perusahaan}

Kondisi awal sumber daya manusia perusahaan menunjukkan jumlah karyawan yang dimiliki oleh perusahaan semakin meningkat setiap tahunnya, khususnya berdasarkan data yang dikumpulkan untuk periode tahun 2004 - 2007 (Gambar 3) dimana jumlah karyawan pada awal tahun lebih kecil dibandingkan jumlah karyawan pada akhir tahun tersebut sebagaimana ditunjukkan dalam grafik berikut ini :

\section{Perbandingan Jumlah Karyawan}

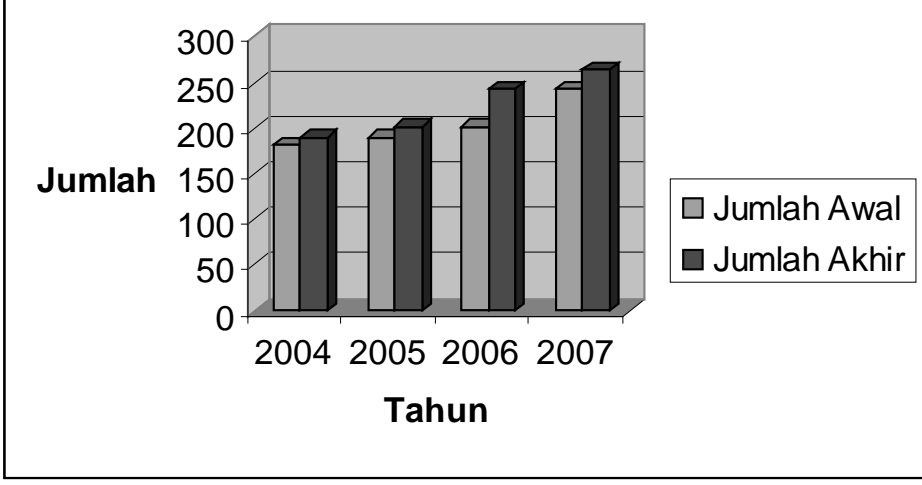

Gambar 3. Jumlah Karyawan Awal dan Akhir Tahun

Selain itu, tingkat turn over karyawan perusahaan yang cukup besar berdasarkan perhitungan Tabel 1. bila dibandingkan dengan tingkat rata-rata turn over karyawan rata-rata perusahaan di Indonesia (19,41\%).

Tabel 1. Turn over Rate Karyawan Tahun 2004- 2007

\begin{tabular}{|l|c|c|c|c|}
\hline \multirow{2}{*}{\multicolumn{1}{c|}{ Data }} & \multicolumn{5}{c|}{ Tahun } \\
\cline { 2 - 5 } & $\mathbf{2 0 0 4}$ & $\mathbf{2 0 0 5}$ & $\mathbf{2 0 0 6}$ & $\mathbf{2 0 0 7}$ \\
\hline Jumlah Karyawan Awal & 182 & 190 & 202 & 243 \\
\hline Jumlah Karyawan Masuk & 18 & 17 & 47 & 37 \\
\hline Jumlah Karyawan Keluar & 10 & 5 & 6 & 15 \\
\hline Jumlah Karyawan Akhir & 190 & 202 & 243 & 265 \\
\hline Jumlah Karyawan Rata-Rata & 186 & 196 & 222.5 & 254 \\
\hline Turn over Rate & $\mathbf{1 5 . 0 5 \%}$ & $\mathbf{1 1 . 2 2 \%}$ & $\mathbf{2 3 . 8 2 \%}$ & $\mathbf{2 0 . 4 7 \%}$ \\
\hline
\end{tabular}

\section{B. Penentuan Kriteria Kebijakan Perusahaan}

Pada bagian ini, kriteria kebijakan yang penting ditentukan dengan pendekatan Delphi-AHP.

Tahap 1: Penentuan panelis dan kriteria

Proses Delphi yang dijalankan pada tahap pertama yaitu penentuan para ahli yang ikut berpartisipasi yaitu berjumlah 5 orang panelis yang berposisi sebagai Direktur dari divisi-divisi yang ada di perusahaan. Pada tahap ini masalah yang dibahas adalah menentukan kriteria-kriteria apa saja yang patut menjadi pertimbangan para panelis 
dalam membuat suatu kebijakan khususnya yang berkaitan dengan pemenuhan kebutuhan sumber daya manusia perusahaan.

Pengumpulan pendapat para panelis dilakukan dengan penyebaran kuesioner yang dilakukan secara terpisah kepada para panelis tersebut. Hasil yang didapat pada proses pertama metode Delphi ini yaitu berupa kriteria-kriteria yang dijabarkan dalam 15 pernyataan (Tabel 2)

Tabel 2. Hasil Proses Delphi Tahap Pertama

\begin{tabular}{|c|l|}
\hline No. & \multicolumn{1}{|c|}{ Pernyataan } \\
\hline 1 & Frekuensi pengontrolan penerapan kebijakan tidak terlalu sering dilakukan \\
\hline 2 & Ruang lingkup pengontrolan tidak terlalu luas \\
\hline 3 & Personil yang digunakan untuk pengontrolan penerapan kebijakan tidak banyak \\
\hline 4 & Kemudahan cara pengontrolan kebijakan \\
\hline 5 & Evaluasi hasil pengontrolan penerapan kebijakan mudah dilakukan \\
\hline 6 & Biaya investasi awal kebijakan tidak besar \\
\hline 7 & Persentase pemakaian biaya dari anggaran perusahaan tidak besar \\
\hline 8 & Biaya rutin yang ditimbulkan kebijakan tidak besar \\
\hline 9 & Biaya pengembangan dan penyempurnaan kebijakan tidak besar \\
\hline 10 & Tidak banyak menimbulkan biaya-biaya lain sebagai akibat penerapan kebijakan \\
\hline 11 & Proses sosialisasi kebijakan kepada karyawan mudah dilakukan \\
\hline 12 & Kebijakan dapat diterapkan untuk jangka waktu lama \\
\hline 13 & Karyawan mudah untuk memahami kebijakan yang dibuat \\
\hline 14 & Pelatihan bagi karyawan terhadap kebijakan tersebut tidak memakan waktu lama \\
\hline 15 & Lama waktu adaptasi karyawan terhadap kebijakan tidak lama \\
\hline
\end{tabular}

\section{Tahap 2: Uji validitas dan reliabilitas kriteria}

Pada tahap kedua pelaksanaan metode Delphi ini masih dilakukan dengan cara penyebaran kuesioner dan dengan kelima orang panelis yang sama seperti pada tahap pertama. Pada tahap ini, penyebaran kuesioner dilakukan untuk mengevaluasi 15 pernyataan yang didapat dari tahap pertama. Evaluasi dilakukan oleh para panelis dengan menggunakan skala Likert 1 sampai 5 untuk menilai tingkat Importance (Kepentingan) dan Desirability (Keinginan). Hasil yang didapat pada tahap kedua ini diuji validitas dan reliabilitasnya.

- Uji Validasi

Uji validitas digunakan untuk mengetahui kelayakan butir - butir dalam suatu daftar (konstruk) pernyataan dalam mendefinisikan suatu variabel. Pada uji validitas dengan menggunakan $n$ (jumlah panelis) $=5$ dan $\alpha=0,05$ didapat nilai r-tabel $=0,775$. Nilai masing-masing pernyataan yang terdapat pada nilai corrected item-total correlation dibandingkan dengan nilai r-tabel dan ternyata lebih besar dari r-tabel, maka butir-butir pernyataan dari kuesioner tersebut dapat dikatakan valid.

- Uji Reliabilitas

Realibilitas (keandalan) merupakan ukuran suatu konsistensi responden dalam menjawab hal yang berkaitan dengan konstruk-konstruk pernyataan yang merupakan 
dimensi suatu variabel dan disusun dalam suatu bentuk kuesioner. Pada uji reliabilitas, angka yang dibandingkan adalah nilai Cronbach's Alpha. Nilai Cronbach's Alpha yang didapat adalah 0,708 >0,60. Berdasarkan hasil tersebut, maka kuesioner dapat dikatakan reliable. Berikut adalah hasil ujinya :

Tabel 3. Hasil Uji Reliabilitas

\begin{tabular}{|c|c|c|}
\hline Cronbach's Alpha & $\begin{array}{c}\text { Cronbach's Alpha } \\
\text { Based on } \\
\text { Standardized Items }\end{array}$ & N of Items \\
\hline $\mathbf{. 7 0 8}$ & .708 & 15 \\
\hline
\end{tabular}

Setelah dinyatakan valid dan reliable, hasil yang didapat dirata-rata dan hasilnya ditampilkan dalam grafik tingkat Importance (Kepentingan) dan Desirability (Keinginan).

\section{Tingkat Importance Pernyataan}

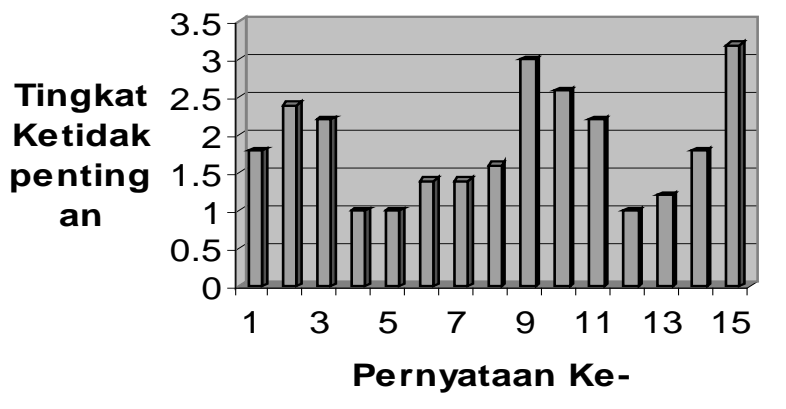

Gambar 4. Grafik Tingkat Importance Pernyataan

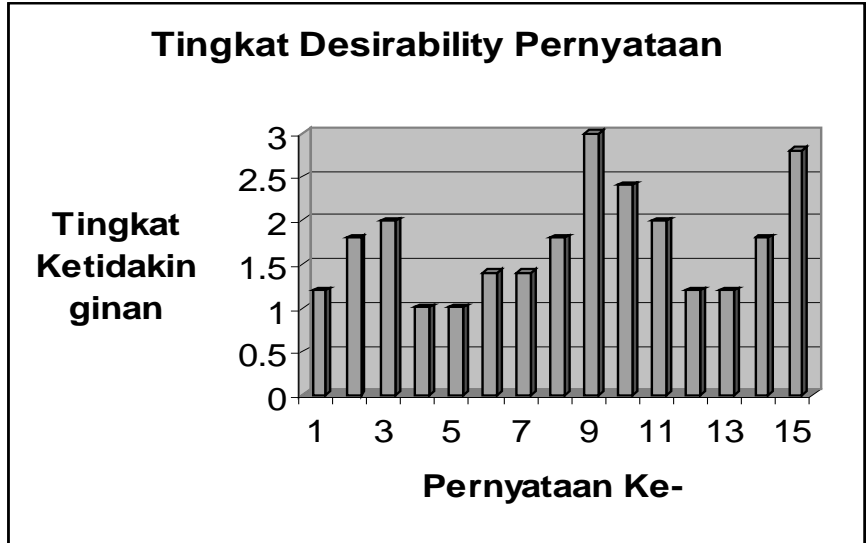

Gambar 5. Grafik Tingkat Desirability Pernyataan

Berdasarkan grafik pada Gambar 4 dan 5, terlihat ada 2 pernyataan yang memiliki nilai rata-rata tinggi atau berarti memiliki tingkat kepentingan dan keinginan yang buruk, yaitu pernyataan nomor 9 yaitu "biaya pengembangan dan penyempurnaan tidak besar" dan pernyataan nomor 15 yaitu "lama waktu adaptasi 
karyawan terhadap kebijakan tidak lama”, sehingga kedua pernyataan tersebut dapat dihilangkan. Ke-13 pernyataan yang tersisa dapat dikelompokkan ke dalam tiga kriteria utama berdasarkan kesamaan hal yang terkandung didalamnya, yaitu (1) Proses monitoring kebijakan, (2) Biaya, dan (3) Kemudahan.

\section{Tahap 3: Uji perbandingan berpasangan kriteria dengan metode AHP}

Pada pelaksanaan proses Delphi tahap ketiga, dilakukan penyebaran kuesioner kembali untuk kelima panelis yang sama. Tahap ketiga ini bertujuan untuk melakukan perbandingan berpasangan terhadap ketiga kriteria besar yang telah dirangkum sebelumnya. Hasil yang diperoleh dari pengajuan kuesioner ini diolah dengan menggunakan pendekatan AHP (Analytical Hierarchy Process) menggunakan software Expert Choice. Penggunaan penedekatan AHP dilakukan dengan tujuan untuk membantu memilih dan mengolah hasil dari metode Delphi. Hasil yang diperoleh sebagai berikut :



\section{Gambar 6. Hasil Pengujian AHP Kriteria Terhadap Goals}

Berdasarkan hasil pengujian, kriteria terpilih adalah kriteria "Biaya” dengan bobot 0,419 yang merupakan bobot tertinggi. Urutan prioritas kriteria kebijakannya yaitu Biaya, Kemudahan, dan Monitoring. Karena kriteria terpilih yaitu "Biaya" tidak memiliki bobot mutlak (> 0,50), sehingga kriteria "Monitoring" dan "Kemudahan" harus tetap dipertimbangkan.

\section{Tahap 4: Uji perbandingan berpasangan sub kriteria terhadap kriteria biaya}

Pada pelaksanaan metode Delphi tahap keempat, dilakukan kembali perbandingan berpasangan terhadap sub-kriteria kriteria biaya dengan tujuan untuk mengetahui lebih jelas sub-kriteria biaya seperti apa yang diinginkan dan dianggap penting oleh para panelis. Item-item sub kriteria Biaya adalah sebagai berikut: 
Tabel 4. Sub-kriteria Kriteria Biaya

\begin{tabular}{|c|l|}
\hline \multicolumn{2}{|c|}{ Sub Kriteria Biaya } \\
\hline No & \multicolumn{1}{|c|}{ Pernyataan } \\
\hline 1 & Biaya investasi awal kebijakan tidak besar \\
\hline 2 & Persentase pemakaian biaya dari anggaran perusahaan tidak besar \\
\hline 3 & Biaya rutin yang ditimbulkan kebijakan tidak besar \\
\hline 4 & Biaya pengembangan dan penyempurnaan kebijakan tidak besar \\
\hline
\end{tabular}

Dengan panelis dan cara penyebaran kuesioner yang sama seperti pada tahap ketiga didapat hasil sbb:

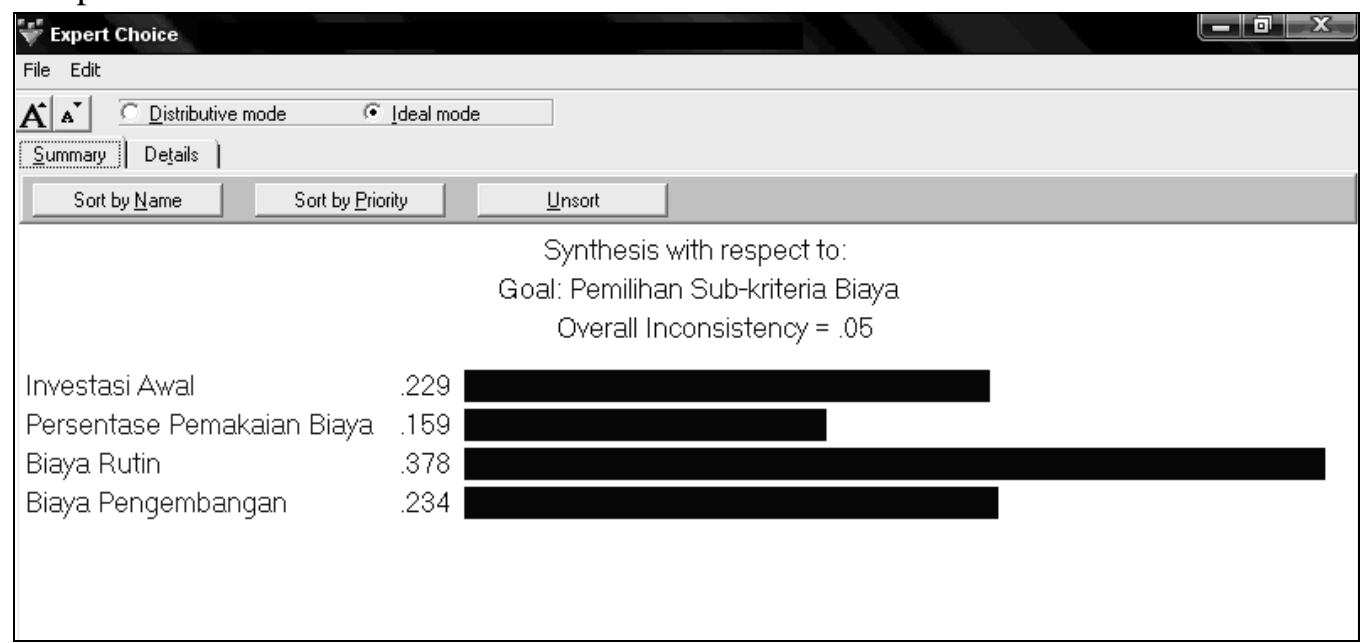

\section{Gambar 7. Hasil Pengujian AHP Sub-kriteria Terhadap Kriteria Biaya}

Berdasarkan hasil pengujian, sub kriteria yang terpilih adalah "Biaya rutin kebijakan tidak besar" dengan bobot 0,378. Sub kriteria yang lain juga patut dipertimbangkan karena terdapat hal-hal yang penting yang terkandung dalam setiap kebijakan yang dibuat perusahaan khususnya di bidang pemenuhan kebutuhan perusahaan akan sumber daya manusia. Hasil rangkuman keseluruhan pelaksanaan metode Delphi dapat dilihat pada Tabel 5.

\section{Tahap 5: Pemilihan alternatif strategi}

Pada tahap ini dilakukan perbandingan hasil sub kriteria terpilih dengan menggunakan metode pengerjaan penilaian secara terpisah terhadap subkriteriasubkriteria yang ada. Hasil yang didapat berbeda yaitu pada tahap ini didapat hasil bahwa subkriteria terpilih adalah biaya investasi kebijakan dan persentase pemakaian biaya kebijakan dengan memperhitungkan keseluruhan subkriteria yang ada. Subkriteria terpilih pada proses Delphi dengan memperhitungkan hanya subkriteria biaya saja adalah biaya rutin. Gambar 8 adalah diagram hirarkinya beserta bobotnya masingmasing. 
Tabel 5. Rangkuman Proses Delphi

\begin{tabular}{|c|c|c|c|c|}
\hline & Tahap 1 & Tahap 2 & Tahap 3 & Tahap 4 \\
\hline Tujuan & $\begin{array}{l}\text { Menentukan } \\
\text { kriteria-kriteria } \\
\text { kebijakan yang } \\
\text { dianggap penting }\end{array}$ & $\begin{array}{c}\text { Menentukan tingkat kepentingan dan } \\
\text { keinginan tiap kriteria, merangkum } \\
\text { kriteria }\end{array}$ & $\begin{array}{c}\text { Memilih } \\
\text { kriteria }\end{array}$ & $\begin{array}{l}\text { Memilih } \\
\text { sub-kriteria } \\
\text { dari kriteria } \\
\text { terpilih }\end{array}$ \\
\hline $\begin{array}{c}\text { Tingkat } \\
\text { Penilaian }\end{array}$ & Subjektif & Skala Kepentingan dan Keinginan & $\begin{array}{l}\text { Perbandin } \\
\text { gan } \\
\text { Berpasang } \\
\text { an dan } \\
\text { AHP }\end{array}$ & $\begin{array}{l}\text { Perbanding } \\
\text { an } \\
\text { Berpasanga } \\
\text { n dan } A H P\end{array}$ \\
\hline $\begin{array}{c}\text { Jumlah } \\
\text { Penyeba } \\
\text { ran } \\
\text { Kuesione } \\
\text { r } \\
\end{array}$ & 1 kali & 2 kali & 1 kali & 1 kali \\
\hline Hasil & 15 pernyataan & $\begin{array}{l}13 \text { pernyataan masuk dalam skala } \\
\text { penting dan diinginkan dan } \\
\text { penghilangan } 2 \text { pernyataan karena tidak } \\
\text { penting dan tidak diinginkan }\end{array}$ & $\begin{array}{l}\text { Kriteria } \\
\text { terpilih } \\
\text { "Biaya" }\end{array}$ & $\begin{array}{l}\text { Sub kriteria } \\
\text { biaya } \\
\text { terpilih } \\
\text { "Biaya } \\
\text { rutin } \\
\text { kebijakan” }\end{array}$ \\
\hline
\end{tabular}

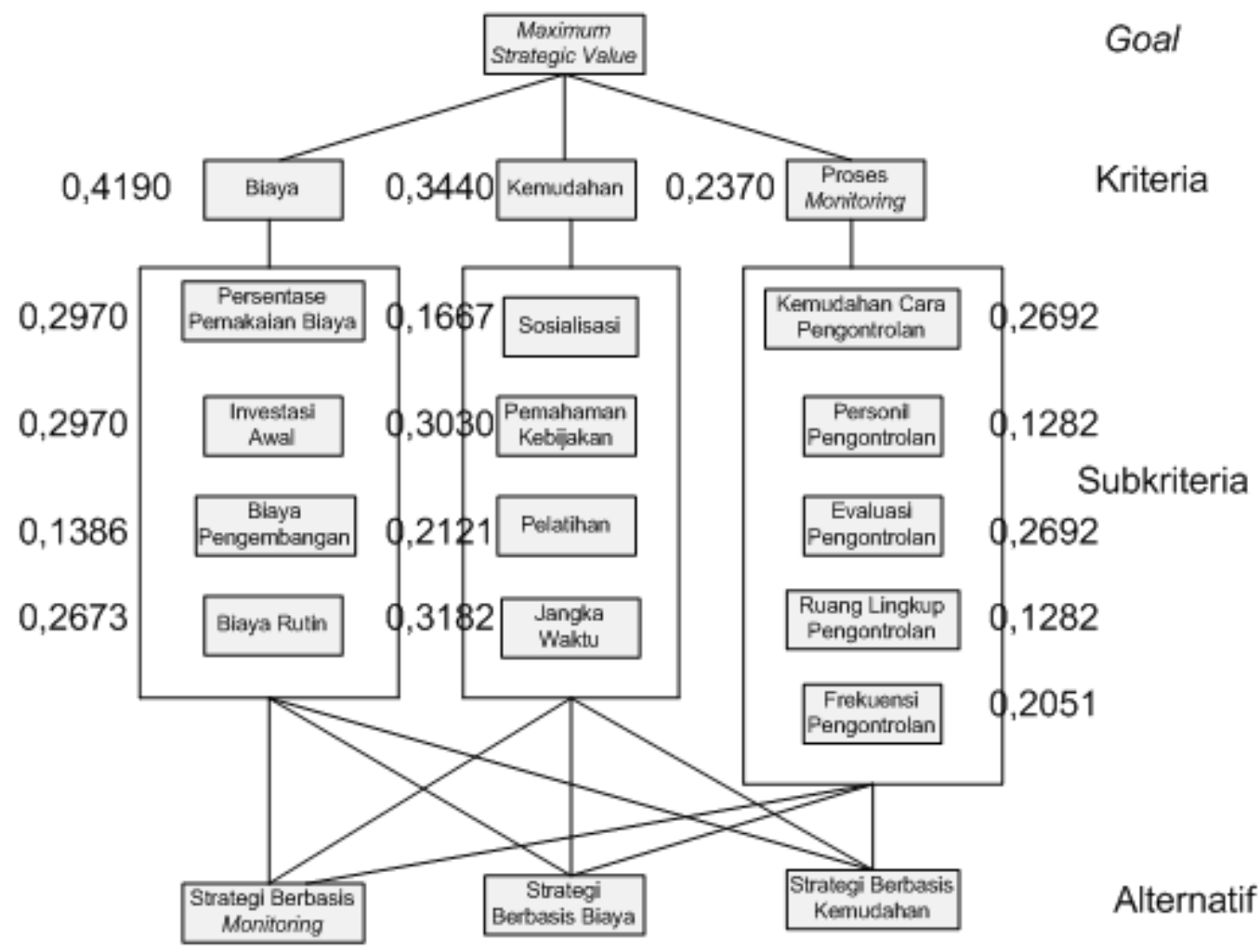

Gambar 8. Diagram Pemilihan Alternatif Strategi 
Setelah mengetahui sub kriteria, diberikan juga 3 alternatif strategi untuk dipilih untuk diterapkan nantinya. Masing-masing alternatif strategi diberi penilaian terhadap tiap sub kriteria dengan skala untuk mengetahui tingkat kepentingannya. Hasil yang didapat adalah alternatif strategi berbasis monitoring memiliki nilai tertinggi yaitu 2,5071, sehingga alternatif strategi ini dapat menjadi bahan pertimbangan pihak perusahaan untuk diterapkan.

\section{Penentuan Jumlah dan Komposisi Karyawan dengan Metode Rantai Markov}

Berdasarkan data perusahaan mengenai jumlah dan komposisi pegawai dan juga struktur organisasi perusahaan, dibentuklah state yang didasarkan atas kesamaan job atau jabatan di antara jabatan yang ada serta kesamaan kesempatan pegawai yang berada pada satu state untuk berpindah ke state yang lebih tinggi. State yang terbentuk ada 5 state serta terdapat 2 state tambahan yaitu untuk menggambarkan penambahan karyawan dan state lainnya untuk menggambarkan pengurangan karyawan perusahaan.

Berdasarkan state dan data jumlah karyawan yang telah dilakukan penyesuaian ke dalam bentuk state, maka berikutnya adalah penghitungan probabilitas dan proporsi perpindahan dari suatu state ke state lainnya. Hasil yang didapat tersebut digunakan untuk membentuk Matriks Probabilitas Transisi (MPT). MPT yang didapat dilakukan validasi yaitu dengan menguji ke-stasioner-an MPT yang didapat dengan bantuan tabel Chi-Square.

Tahap selanjutnya adalah dengan menggunakan software Curve Expert untuk mendapatkan rumus yang sesuai dengan sifat data dan dengan tingkat error terkecil untuk meramalkan jumlah kebutuhan pegawai perusahaan pada tahun 2008-2010 berdasarkan data tenaga kerja tahun 2004-2007. Sifat data jumlah tenaga kerja tahun 2004-2007 mengikuti model MMF dan rumus serta nilai koefisien rumus yang didapat adalah :

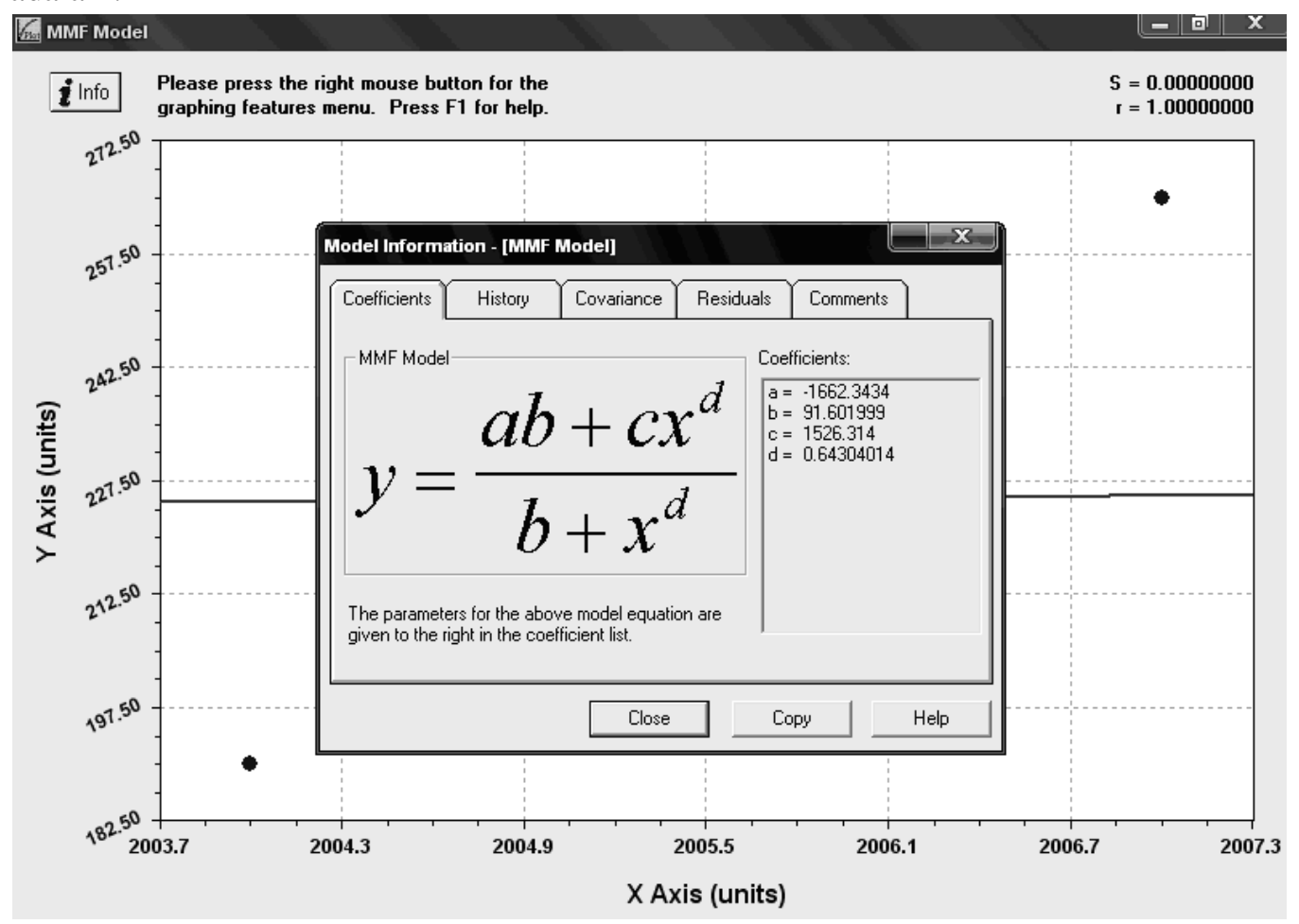

Gambar 9. Rumus Peramalan Jumlah Tenaga Kerja 
Berdasarkan jumlah tenaga kerja yang didapat dari hasil peramalan tersebut serta MPT Tanspose dan komposisi pegawai tahun 2007 dapat dijadikan titik awal untuk merencanakan jumlah dan komposisi pegawai untuk satu tahun ke depan yaitu 2008. Hasil jumlah dan komposisi pegawai tahun 2008 yang didapat berdasarkan peramalan dapat dijadikan dasar peramalan untuk tahun 2009 dengan tetap menggunakan MPT Transpose dan hasil peramalan tenaga kerja dengan Curve Expert tersebut. Hal yang sama berlaku untuk meramalkan jumlah dan komposisi tenaga kerja untuk tahun 2010, dst. Rangkuman hasil perencanaan kebutuhan jumlah dan komposisi tenaga untuk tahun 2008-2010 sebagai berikut :

Tabel 6. Rangkuman Perencanaan Jumlah dan Komposisi Pegawai

\begin{tabular}{|c|c|c|c|}
\hline \multirow{2}{*}{ State } & \multicolumn{3}{|c|}{ Tahun } \\
\cline { 2 - 4 } & $\mathbf{2 0 0 8}$ & $\mathbf{2 0 0 9}$ & $\mathbf{2 0 1 0}$ \\
\hline I & 5 & 5 & 5 \\
\hline II & 5 & 5 & 5 \\
\hline III & 8 & 8 & 8 \\
\hline IV & 75 & 69 & 72 \\
\hline V & 133 & 121 & 135 \\
\hline
\end{tabular}

di mana masing-masing state tersebut terdiri dari jabatan :

Tabel 7. Pembagian State

\begin{tabular}{|c|c|}
\hline State & Jabatan \\
\hline I & Direktur \\
\hline II & Wakil Direktur \\
\hline III & Manajer \\
\hline IV & $\begin{array}{c}\text { Wakil, Wakil Sipil, Wakil Renovasi, SI, Ass. Marketing Manajer, } \\
\text { Ass. Manajer Logistik, Security, Kasir, Acc, Adm Keuangan }\end{array}$ \\
\hline V & $\begin{array}{c}\text { Kabag, Pelaksana, Supervisor, Apartment Attd, Marketing Adm, } \\
\text { Sales, Rent, MRD, Purchasing Adm, Inventory, Warehouse }\end{array}$ \\
\hline
\end{tabular}

Dengan menggunakan rumus peramalan yang didapat dari Curve Expert, dilakukan peramalan terhadap jumlah pegawai untuk tahun 2004-2007 untuk dilakukan perbandingan dengan jumlah nyata sehingga dapat dihitung error peramalannya. Nilai rentang error yang didapat antara 7\% - 19\%. Dengan rentang error tersebut, model MMF merupakan yang terbaik (berdasarkan hasil Curve Expert) dan dinilai tidak besar. 


\section{KESIMPULAN DAN SARAN}

\section{A. Kesimpulan}

Dari hasil penelitian ini, dapat disimpulkan beberapa hal sebagai berikut:

1. Dalam studi empiris ini, model Delphi digunakan untuk memilih kriteria-kriteria kebijakan yang penting menurut para panelis, yaitu kriteria biaya, proses monitoring, dan kemudahan.

2. Kriteria dan sub-kriteria kebijakan yang didapat dari hasil pelaksanaan metode DelphiAHP tidak memiliki perbedaan bobot cukup besar. Hal ini menunjukkan bahwa kriteria dan sub kriteria tersebut juga penting dalam kebijakan perencanaan sumber daya manusia perusahaan. Dalam penelitian ini, kriteria kebijakan terpilih adalah kriteria 'biaya' dengan sub-kriteria biaya terpilih adalah 'biaya rutin kebijakan yang tidak besar'.

3. Pada pemilihan sub kriteria dengan memperhitungkan seluruh sub kriteria, hasil yang didapat berbeda dengan hasil proses Delphi sebelumnya. Sub kriteria yang terpilih adalah 'biaya investasi awal' dan 'persentase pemakaian biaya'.

4. Pada analisis rantai Markov pada penelitian ini, sifat-sifat variabel didasarkan pada peluang perpindahan tenaga kerja dari suatu state ke state lainnya. Perencanaan jumlah dan komposisi kebutuhan pegawai pada PT. BM dilakukan untuk 3 tahun ke depan.

\section{B. Saran}

Berikut ini beberapa hal yang dapat menjadi saran untuk perusahaan dan penelitian yang akan datang, yaitu :

1. Perusahaan sebaiknya memiliki suatu sistem perencanaan sumber daya manusia agar dapat menghindari terjadinya kekurangan ataupun kelebihan pegawai dari yang dibutuhkan. Prosedur perencanaan yang telah diusulkan pada penelitian ini dapat dipertimbangkan untuk dapat dijadikan pedoman bagi perusahaan untuk merencanakan sumber daya manusianya.

2. Hasil pemilihan alternatif strategi didapat bahwa alternatif strategi berbasis monitoring memiliki nilai tertinggi dibandingkan dua alternatif strategi lainnya, sehingga alternatif strategi ini dapat dipertimbangkan untuk dipilih oleh pihak manajemen untuk diterapkan di perusahaan.

3. Hasil perencanaan sumber daya manusia usulan dalam penelitian ini dapat dilakukan revisi, pembaharuan, ataupun penyempurnaan secara periodik jika terdapat perubahan pada situasi dan kondisi perusahaan.

4. Berkaitan dengan masalah tingkat turn over pegawai yang besar, perlu dilakukan penelitian lebih lanjut oleh pihak manajemen mengenai akar penyebab tingginya tingkat turn over karyawan perusahaan. Beberapa hal yang mungkin dapat menjadi penyebabnya diantaranya seperti besarnya gaji, kondisi lingkungan kerja, peraturan kerja, dan lain-lain.

\section{DAFTAR PUSTAKA}

[1] Andrean, L., 2008, Perencanaan Sumber Daya Manusia dengan Menggunakan Metode Policy Delphi dan Rantai Markov, Tugas Akhir Jurusan Teknik Industri, Unika Atma Jaya, Jakarta.

[2] Belcourt, M. and McBey, K.J., 2004, Strategic Human Resources Planning, 2nd ed., Nelson Series in Human Resources, Thompson Canada.

[3] Burack, E.H., 1986, Corporate Business and human Resources Planning Practices: Strategic Issues and Concerns, Organizational Dynamics, 15(1), 73-87.

[4] Dessler, G., 1997, Manajemen Sumber Daya Manusia, Terj., Prenhallindo, Jakarta.

[5] Gordon, T.J., 1994, The Delphi Method, Millenium, London. 
[6] Jackson, S.E. and Schuller, R.S., 1995, Understanding Human Resources Management In The Context Of Organizations and Their Environments, Annual Review of Psychology, 26, 237-264.

[7] Linstone, H. and Turoff, M., 2002, The Delphi Method Techniques and Application, Murray Turoff \& Harold A. Linstone Inc., London.

[8] McClean, S., 1991., Manpower Planning Models and Their Estimation, European Journal of Operational Research, 51(2), 179-187.

[9] Meehan, R. and Ahmed, B.S., 1990, Forecasting Human Resources Requirements: A Demand Model, Human Resources Planning, 13(4), 297-307.

[10] Noe, R., Mondy, W., and Premeaux, S., 1999. Human Resources Management. International Edition, Seventh Edition, Prentice Hall, New Jersey.

[11] Rothwell, S., 1986, Planning for Human Resources - Essay Review, Long Range Planning, 19(5), 109-112.

[12] Saaty, T.L., 1980, The Analytic Hierarchy Process, McGraw Hill, New York.

[13] Siswanto, B., 1989, Manajemen Tenaga Kerja, Sinar Baru, Bandung.

[14] Taha, H.A., 1982, Operation Research: An Introduction, Third Edition, MacMillan Publishing Co., New York.

[15] Stewman, S., 1978, Markov and Renewal Models for Total Manpower System, Omega, 6(4), 341-351.

[16] Wijaya, E., 2006, Perencanaan Jumlah dan Komposisi Tenaga Kerja Dengan Pendekatan Rantai Markov, Tugas Akhir Jurusan Teknik Industri, Unika Atma Jaya, Jakarta.

[17] Zanarkis, S.H. and Martin, W., 1980, A Markov Chain Application to Manpower Supply Planning, The Journal of the Operation Research Society, 31(12), 1095-1102. 